\title{
ECONOMIC AND SOCIAL IMPACT OF COVID- 19 PANDEMIC ON GLOBAL SCALE AND IN THE CASE OF THE REPUBLIC OF NORTH MACEDONIA
}

\author{
Marica Antovska-Mitev', Tatjana Drangovska²
}

\author{
${ }^{1}$ MANU, Center for Strategic Research "Ksente Bogoev", Krste Misirkov Blvd., 2, Skopje, \\ North Macedonia, mantovska@manu.edu.mk \\ ${ }^{2}$ MANU, Center for Strategic Research "Ksente Bogoev", Krste Misirkov Blvd., 2, Skopje, \\ North Macedonia, tatjana.drangovska@manu.edu.mk
}

\begin{abstract}
The COVID-19 pandemic has affected about 220 countries with more than 178 million confirmed cases and over 3.8 million mortalities worldwide. North Macedonia belongs among the severely affected countries by the COVID-19 pandemic, which by the mid-June 2021, resulted with over 155 thousand confirmed cases or 7.470 cases per 100.000 inhabitants and 263 mortalities per 100.000 inhabitants. The crisis caused by the COVID-19 pandemic, that began as a health crisis in a short time has grown into an economic and social crisis, which led to the strongest short term decline in the global economic activity in the past 150 years. This crisis besides the health and economic implications has also contributed to social instabilities. Economic and social implications of the COVID-19 crisis on global scale and in the case of the Republic of North Macedonia are further analyzed within the paper. Analyzes of the economic impacts of the crises is based on the movement of the key macroeconomic indicators as: GDP growth rates, unemployment rates, Gross debt, etc. Analyzes of the social impacts of the crises is focused on the reduced incomes, increased inequality in income distribution and poverty growth. At the end of the paper is given summery overview of socioeconomic impacts caused by COVID-19 pandemic in the country and there are designed some proposals to policy makers applicable in the later stages of the crisis and in the period of economic recovery. This proposals are aimed to support the process of reaching the forecast growth rates and to increase the investment process and private consumption in the country, in direction of achieving sustainable growth in future.
\end{abstract}

Key words: COVID-19 pandemic, economic implications, social implications, economic growth.

\section{Introduction}

Today we are all witnesses of the new health, economic and social crisis caused by the COVID-19 pandemic that has inflicted on the world the worst impact in the last hundred years, 
testing the resilience of modern societies, economies, health systems and welfare systems like never before.

The initial spark that marked the beginning of the health crisis was the first identified pneumonia case infected of unknown cause on November 18, 2019, in Wuhan, China. Wuhan, the largest metropolitan area in Hubei province of China, reported for the first time clusters of cases that had unexplained low respiratory infections to the WHO country office on December 31, 2019. On January 9, 2020, a new coronavirus was identified, for which genetic sequencing determined that it belonged to the beta-corona strain ${ }^{1}$. On February 11, 2020, the WHO named the pneumonia as coronavirus disease-19 also known as COVID-19 (Li et al. 2020; Waris et al. 2020).

The coronavirus epidemic that started in China quickly spread to Europe and the United States and affected many countries worldwide and a relatively large percentage of the world's population, gaining scale of a pandemic. At the end of January 2020, just over a month after the outbreak of the coronavirus in China, according to WHO data, 20 countries had reported cases of COVID-19 infected persons, in order to at the end of February 2020, the number of countries that have reported the existence of the virus to increase to 54 countries.

The COVID-19 pandemic, which was officially declared on March 11, 2020 by the WHO Secretary General, has affected 223 countries worldwide by mid-June 2021. As per the current statistics reported by the WHO, there have been 178.118 .597 confirmed cases of COVID-19 globally, 3.864.180 mortalities have been reported and a total of 2.412.226.768 vaccine have been administered (WHO 2021).

Although the infection has spread worldwide, it has not affected all countries equally. Among the hardest hit countries, at the beginning of the pandemic, have been the highly developed countries, led by the United States, Great Britain, Italy, Spain, Germany, France and Turkey, where the number of infected people, by country, reached more than 100.000 by May 2020 . As of now, the USA, followed by India, Brazil, France, Turkey, Russia and United Kingdom have reported the highest number of positive cases (Table 1).

Table 1. Statistics of top 10 COVID-19-affected countries (as of June 20, 2021)

\begin{tabular}{|c|c|c|c|c|}
\hline & Country & Confirmed cases & Total deaths & $\begin{array}{l}\text { Transmission } \\
\text { classification }\end{array}$ \\
\hline 1 & United States of America & 33.190.195 & 596.003 & Community transmission \\
\hline 2 & India & 29.935.221 & 388.135 & Clusters of cases \\
\hline 3 & Brazil & 17.883 .750 & 500.800 & Community transmission \\
\hline 4 & France & 5.648 .210 & 109.826 & Community transmission \\
\hline 5 & Turkey & 5.365 .208 & 49.122 & Community transmission \\
\hline 6 & Russian Federation & 5.316 .826 & 129.361 & Clusters of cases \\
\hline 7 & The United Kingdom & 4.620 .972 & 127.970 & Community transmission \\
\hline 8 & Argentina & 4.258 .394 & 88.742 & Community transmission \\
\hline
\end{tabular}

\footnotetext{
${ }^{1}$ Coronaviruses (CoV) are a large family of viruses that cause diseases ranging from the common cold to more severe diseases (SARS-CoV, MERS-CoV). The coronavirus (SARS-CoV2) is a new type of coronavirus that has not been previously identified in humans and causes a disease called COVID-19. Common symptoms and signs of infection include fever, cough, and difficulty breathing. In more severe cases, the infection can cause pneumonia, severe acute respiratory syndrome, renal failure and even death. There is no specific treatment, similar to most viruses. However, many of the symptoms can be treated and therefore treatment should be based on the patient's clinical condition (http://zdravstvo.gov.mk/wp-content/uploads/2020/03/info-COVID-19-22.03.pdf).
} 


\begin{tabular}{|l|l|c|c|l}
\hline $\mathbf{9}$ & Italy & 4.252 .095 & 127.253 & Clusters of cases \\
\hline $\mathbf{1 0}$ & Colombia & 3.917 .228 & 80634 & Community transmission \\
\hline
\end{tabular}

Source: WHO 2021.

COVID-19 infection that was rapidly spread from China to Europe, to the United States and to the other parts of the world, in a short time was transmitted to North Macedonia, where the very first positive case of COVID-19 (zero patient) was reported on February 26, 2020. The quick reaction of the health authorities and the numerous lockdown measures taken as a response to the spread of the new coronavirus enabled the situation in the country to be kept under control in the first few months after the start of the pandemic.

North Macedonia until now, has faced two peaks during the COVID-19 pandemic (Graph 1). The first peak of contamination is mid-December 2020, after which, the number of active COVID-19 cases has been steadily decreasing (OECD 2021). The second peak of contamination is mid-April 2021. On April 8, 2021, the economy had 22.164 active cases and 138.891 cases in total. Two weeks later, the situation has been slightly improved, i.e., on April 20, 2021, North Macedonia had 18.658 active cases, 6.918 cases per 100.000 inhabitants and 147.995 cases in total (IPH 2021).

\section{Graph 1. Evolution of active cases in North Macedonia}

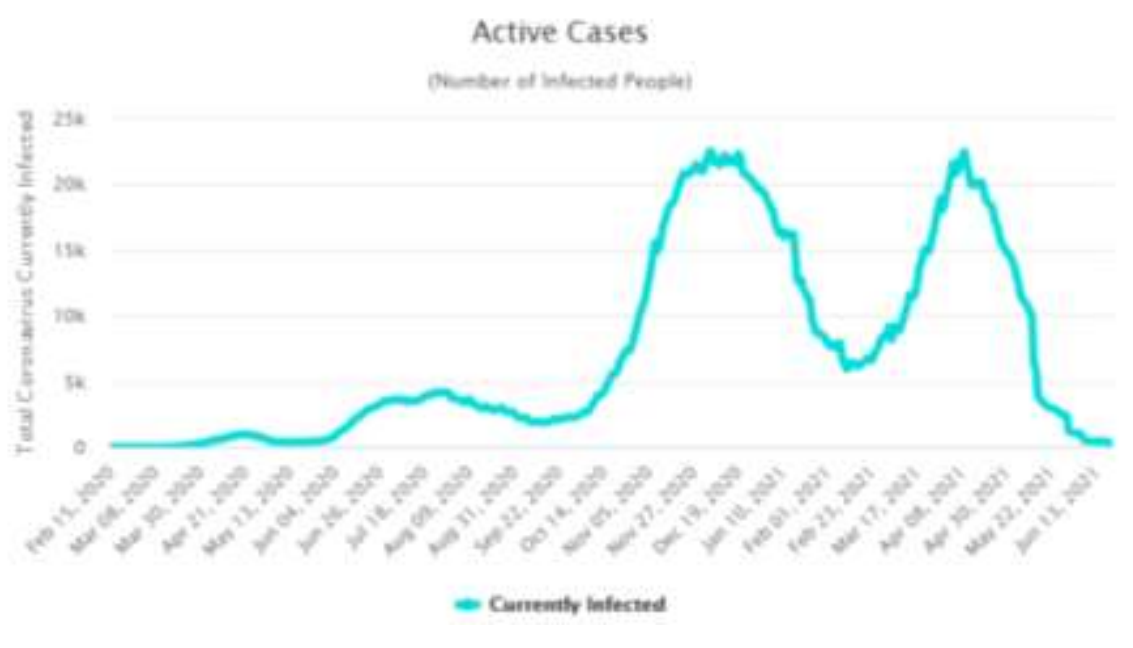

Source: Worldometers.info.

According to the current statistics reported by the Ministry of health, in North Macedonia, as of June 20, 2021, there are 155.627 confirmed cases, 5.477 mortalities, 149.877 recovered cases and 273 active cases (Graph 2).

Graph 2. COVID-19 outbreak figures of North Macedonia (as of June 20, 2021) 


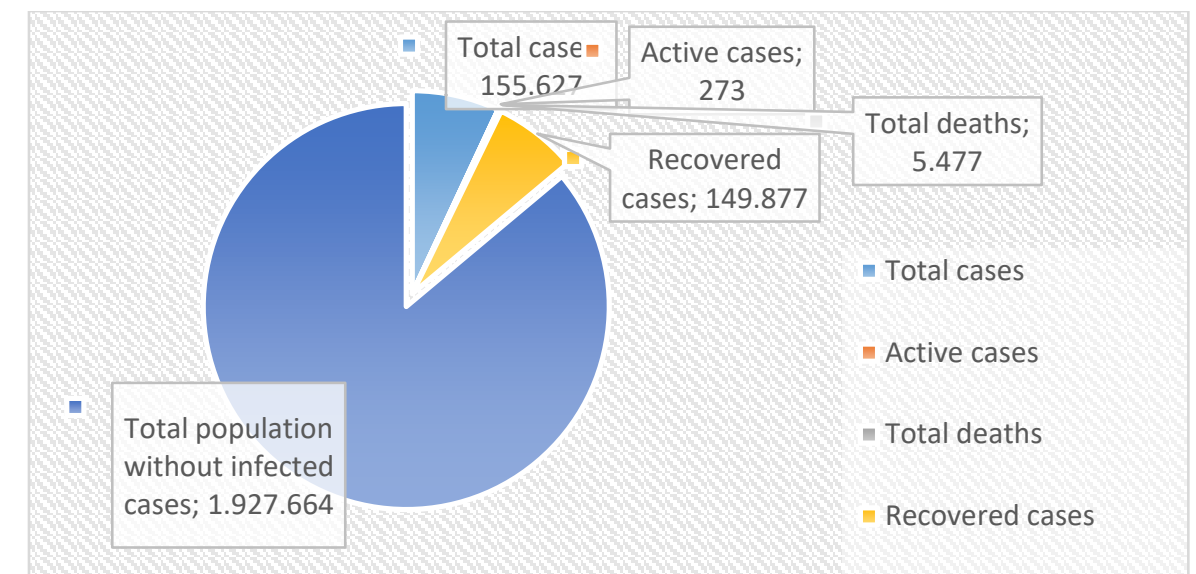

Source: Ministry of Health 2021, Worldometers 2021 and authors' calculations.

The countries efforts to slow the spread of the virus and to save human health have resulted in the closure of numerous economic activities. The need to maintain social and physical distance, quarantines, self-isolation of people, job restrictions, severance of trade ties and isolation of countries have contributed to the closure of entire economic sectors, especially the hospitality and tourism sectors, parts of the transport sector, trade and processing industry, as well as education, culture, sports, etc.

All this contributed the new crisis caused by the COVID-19 pandemic, which initially appeared as a health crisis, quickly to grow into an economic and social crisis.

\section{Socio-economic impacts of COVID-19 pandemic on global scale}

Short-term fluctuations in the economic activity, so-called business cycles, are among the most complex and the most challenging questions in the macroeconomic science. Economists define business cycles as fluctuations in the aggregate economic activity. Within these fluctuations many economic variables (real gross domestic product, industrial production, investment, real income, employment, etc.) are rising or falling together and such tendency is constantly repeated, but at irregular and unpredictable time intervals. The term economic crises refer to the downward phase of business cycles, so-called recession.

The economic crisis caused by the COVID-19 pandemic belongs among the great (severe) economic crises, which led to the strongest short-term decline in the global economic activity in the past 150 years. The crisis caused a big shock on the aggregate supply side that was transmitted simultaneously to the aggregate demand side. This pushed the world economy into a severe recession.

Considering that the new crisis is determined by the health sector, and not by economic factors, as it was the case with previous crises, including the Great Recession 2007-2009, this is a very specific crisis characterized with numerous risks and huge uncertainty.

COVID-19 pandemic has caused a serious decline in economic activity worldwide.

The initial forecast of the International Monetary Fund (IMF), from April 2020, based mainly on the assumption that the pandemic will subside in the second half of 2020 , predicted decline in world GDP of $3 \%$ by the end of 2020 , a decline in developed countries GDP of $6.1 \%$, Eurozone GDP decline of $7.5 \%$, US GDP decline of $5.9 \%$, etc. (IMF 2020a).

The reduction of the restrictive measures in mid-2020, which were introduced at the beginning of the crisis to protect public health, led to an intensification of the pandemic again. That contributed the forecasts of the relevant world institutions for the movement of economic 
activity to be revised, mainly downwards. Thus, the initial forecasts of the IMF (from April 2020) for a decline in the world output rate of $-3 \%$, in June were corrected to $-4.9 \%$, for the group of developed countries from $-6.1 \%$ to $-8.0 \%$, in the Eurozone from $-7.5 \%$ to $-10.2 \%$, in the USA from $-5.9 \%$ to $-8.0 \%$, etc. (IMF $2020 \mathrm{~b}$ ).

According to the current data, the short-term decline in the global economic activity was strongest in the second quarter of 2020 (Eurostat 2021a).

According to the estimate published by Eurostat, GDP decreases by $14.6 \%$ in the euro area (EA-19) and $13.8 \%$ in the EU-27 during the second quarter of 2020, compared with the same quarter of the previous year. Compared with the previous quarter, GDP decreased by $11.6 \%$ in the euro area and by $11.2 \%$ in the EU-27. In Japan and United States, GDP decreases by $10.3 \%$ and $9.0 \%$, respectively, during the second quarter of 2020 , compared with the same quarter of the previous year.

In the third and fourth quarters a significant recovery of the EU economies and world economies is evident. Compared with the same quarter of the previous year, seasonally adjusted GDP decreased by $4.9 \%$ in the euro area and by $4.6 \%$ in the EU-27 in the fourth quarter of 2020 , after $-4.1 \%$ in the euro area and $-4.0 \%$ in the EU-27 in the previous quarter. During the fourth quarter of 2020, GDP in the United States increased by $1.1 \%$ compared with the previous quarter (after $+7.5 \%$ in the third quarter of 2020). Compared with the same quarter of the previous year, GDP decreased by $2.4 \%$ (after $-2.8 \%$ in the previous quarter).

Such movements in GDP growth rates have contributed the most countries in the world as well as the EU countries to finish 2020 with a strong decline in economic activity.

The decline of economic activity in 2020 among the euro area (EA-19) is $-6.6 \%$ and among the EU-27 is $-6.1 \%$, compared with the previous year.

The IMF forecasts for the impact of the COVID-19 pandemic on the world output (by regions and by individual countries) during 2021 are more optimistic than those during 2020. The IMF, in January 2021, projected global economic growth at $6 \%$ in 2021 , moderating to $4.4 \%$ in 2022 (Table 2).

Table 2. World Economic Outlook Growth Projections (real GDP, annual percent change)

\begin{tabular}{|c|c|c|c|}
\hline & 2020 & 2021 & 2022 \\
\hline World Output & -3.3 & 6.0 & 4.4 \\
\hline Advanced economies & -4.7 & 5.1 & 3.6 \\
\hline United States & -3.5 & 6.4 & 3.5 \\
\hline Euro Area & -6.6 & 4.4 & 3.8 \\
\hline Japan & -4.8 & 3.3 & 2.5 \\
\hline United Kingdom & -9.9 & 5.3 & 5.1 \\
\hline Canada & -5.4 & 5.0 & 4.7 \\
\hline Other Advanced Economies & -2.1 & 4.4 & 3.4 \\
\hline Emerging Market and Developing Economies & -2.2 & 4.4 & 3.4 \\
\hline Emerging and Developing Asia & -1.0 & 8.6 & 6.0 \\
\hline China & 2.3 & 8.4 & 5.6 \\
\hline India & -8.0 & 12.5 & 6.9 \\
\hline Emerging and Developing Europe & -2.0 & 4.4 & 3.9 \\
\hline Latin America and the Caribbean & -7.0 & 4.6 & 3.1 \\
\hline Middle East and Central Asia & -2.9 & 3.7 & 3.8 \\
\hline Low income Developing Country & 0.0 & 4.3 & 5.2 \\
\hline
\end{tabular}

Source: IMF 2021. 
The IMF forecasts from April 2021 are even more favorable and they reflect "... the additional fiscal support in a few large economies and the anticipated vaccine-powered recovery in the second half of the year" (IMF 2021, p. xvi).

However, the uncertainty of the forecasts remains and the final implications of the crisis will depend on the trajectory of the health crisis, the structure of the economies, the effectiveness of the policies for dealing with the crisis and so on.

The crisis caused by the COVID-19 pandemic also led to serious distortions in the labor market.

Estimates of the International Labor Organization (ILO), in May 2020, was that over $94 \%$ of the world's workers continued to reside in countries with some sort of workplace closure measure in place. Working-hours losses, for the second quarter of 2020 relative to the last quarter of 2019 , ILO estimated at $10.7 \%$ worldwide, which is equivalent to 305 million full-time jobs (ILO 2020).

Table 3. Drop in working hours in the first and second quarters of 2020 (percentage)

\begin{tabular}{|l|c|c|}
\hline & $\begin{array}{c}\text { Q1 of 2020 relative to } \\
\text { the Q4 of 2019 }\end{array}$ & $\begin{array}{c}\text { Q2 of 2020 relative to } \\
\text { the Q4 of 2019 }\end{array}$ \\
\hline World & 4.8 & 10.7 \\
\hline Low-income countries & 1.7 & 8.8 \\
\hline Lower-middle-income countries & 1.9 & 11.4 \\
\hline Upper-middle-income countries & 8.8 & 9.9 \\
\hline High-income countries & 2.3 & 12.2 \\
\hline Africa & 1.7 & 9.5 \\
\hline Americas & 1.7 & 13.1 \\
\hline Arab States & 2.1 & 10.3 \\
\hline Asia and Pacific & 6.5 & 10.0 \\
\hline Europe and Central Asia & 3.0 & 12.9 \\
\hline
\end{tabular}

Source: ILO 2020.

The percentage of projected working-hours losses in the second quarter of 2020 relative to the first quarter of 2020 worldwide, has doubled, and in some regions and groups of countries it has grown at even faster pace (Table 3). In December 2019, the unemployment rate in the United States reached a record low level of only 3.5\%, to rise to $14.2 \%$ in April 2020 - the highest level of unemployment rate since the period after the Great Depression 1929-1933. Furthermore, in Canada, in just two months, 2 million jobs were lost, and rapid growth rates of unemployment, with a short time lag, were observed in many other countries affected by the coronavirus pandemic. According to ILO's estimates from January 2021, working-hour losses in 2020 worldwide were approximately four times greater than during the Global financial crisis in 2009.

The latest ILO estimates for working-hours losses in 2020 on a global scale and in the third and fourth quarters of 2020, relative to the fourth quarter of 2019, are shown in Table 4.

Table 4. Working-hours losses, world and by income group, 2020 total and quarterly estimates (percentage)

\begin{tabular}{|l|c|c|c|}
\hline & Total in 2020 & Q3 2020 & Q4 2020 \\
\hline World & 8.8 & 7.2 & 4.6 \\
\hline Low-income countries & 6.7 & 7.6 & 3.3 \\
\hline Lower-middle-income countries & 11.3 & 9.3 & 4.5 \\
\hline
\end{tabular}




\begin{tabular}{|l|l|l|l|}
\hline Upper-middle-income countries & 7.3 & 5.6 & 3.9 \\
\hline High-income countries & 8.3 & 7.3 & 7.0 \\
\hline
\end{tabular}

Source: ILO 2021.

Analyzed data (Table 3 and Table 4), shows that half of the working-hours losses in 2020 occurred in the second quarter of 2020 and in the third and fourth quarters of 2020 the number of working-hours losses is significantly declined.

According to Eurostat data, the EU-27 unemployment rate, increased from $6.7 \%$ in the first quarter of 2020 to $7.5 \%$ in the third quarter of 2020 (Eurostat 2021b).

Also, ILO's Reports emphasize that young workers were particularly hard hit by the crisis in 2020 across all regions and country income groups, resulting in an employment loss of $8.7 \%$, as opposed to $3.7 \%$ for adults (ILO 2021).

Unemployment is a pro-cyclical category which in periods of recession, increases with the decline of production, but regularly with a certain time lag. In this type of crisis, unemployment is growing very fast, i.e. the time lag is much shorter, which is one of its characteristics. According to Professor Larry Summers, while during the Great Recession 2007-2009, economies faced permanent job losses, during the Great Shutdown caused by the coronavirus pandemic, economies faced no permanently but with temporary dismissal.

COVID-19 crisis, besides health and economic component has a strong social component. The accelerated process of job losses and increased unemployment determine strong social implications, such as: reduced incomes, increased inequality in income distribution and growth of poverty worldwide. Despite rising unemployment, social consequences of the crisis are associated to the closure of a huge number of educational institutions worldwide. In February, March and April 2020, nearly 1.6 billion students worldwide were affected by the closure of pre-schools, primary schools, secondary schools and higher education institutions. The social costs of the pandemic are directly related to the increased unemployment, i.e. to the humanitarian and psychological consequences of the unemployed, which are difficult to measure. These costs also include the loss of human lives during the pandemic. They deliver consequences to economies, mainly through increased mortality rates that affect labor supply in the short, medium and long term. Here also should be included the costs that societies and economies will incur in the field of human capital formation - temporary closure of educational institutions at all levels of education, negative consequences related to the distance learning due to problems with poor digitalization in middle and low-income countries, interrupted and postponed specializations and study stays abroad, problems in the implementation of training programs for employees in the business sector, etc.

The declaration of the COVID-19 pandemic, the sharp decline in world production and the deepening recession in the first few months of 2020 was the reason for the countries worldwide to react quickly and to activate the monetary and fiscal policy mechanisms to deal with the crisis.

In such circumstances, central banks worldwide acted mainly through two monetary policy measures - reducing the reference interest rates and increasing the quantitative easing. But taking into account the existence of the so-called liquidity trap globally, among economists today there is a broad consensus on the greater effectiveness of fiscal policy in dealing with crises of this scale.

The measures in the field of fiscal policy that governments have begun to implement in dealing with the crisis, although with some differences between the countries, are mainly related to: supporting the most affected economic sectors, transfers to ensure the liquidity of the companies, subsidizing salaries, targeted transfers to the socially most vulnerable families, 
energy subsidies and capital investments (expenditure side of the budget), as well as deferral of tax payments to households and companies and other tax incentives (revenue side of the budget).

The implementation of the Expansive Fiscal Policy to deal with the severe impact of the crisis caused by COVID-19, in a short time led to a rise in budget deficits and accumulation of public debt of the most world economies.

Revised estimates of the IMF, from January 2021, related to General Government Fiscal Balance and Gross Debt, are shown in Table 5.

Table 5. General Government Fiscal Balance and Gross Debt, 2020-2021 (Percent of GDP)

\begin{tabular}{|c|c|c|c|c|}
\hline & \multicolumn{2}{|c|}{$\begin{array}{l}\text { General Government } \\
\text { Fiscal Balance }\end{array}$} & \multicolumn{2}{|c|}{ Gross Debt } \\
\hline & 2020 & 2021 & 2020 & 2021 \\
\hline World & -11.8 & -8.5 & 97.6 & 99.5 \\
\hline Advanced Economies & -13.3 & -8.8 & 122.7 & 124.9 \\
\hline United States & -17.5 & 11.8 & 128.7 & 132.5 \\
\hline Euro Area & -8.4 & -5.9 & 98.1 & 99.0 \\
\hline Germany & -5.1 & -3.4 & 70.0 & 69.9 \\
\hline France & -10.6 & -7.7 & 115.3 & 117.6 \\
\hline Japan & -13.8 & -8.6 & 258.7 & 258.7 \\
\hline United Kingdom & -14.5 & -10.6 & 103.3 & 110.8 \\
\hline Canada & -20.0 & -7.8 & 115.7 & 116.4 \\
\hline Australia & -10.4 & -11.4 & 63.8 & 74.8 \\
\hline Korea & -3.1 & -2.7 & 48.1 & 53.0 \\
\hline $\begin{array}{l}\text { Emerging Market and Middle Income } \\
\text { Economies }\end{array}$ & -10.3 & -8.6 & 63.3 & 65.3 \\
\hline China & -11.8 & -11.0 & 65.2 & 69.4 \\
\hline India & -11.5 & -9.7 & 85.5 & 83.1 \\
\hline Russia & -4.6 & -2.3 & 21.0 & 20.7 \\
\hline Turkey & -7.4 & -7.1 & 40.4 & 40.3 \\
\hline Brazil & $-14,5$ & -5.0 & 95.6 & 92.1 \\
\hline Mexico & -5.2 & -3.4 & 63.0 & 63.0 \\
\hline Low Income Developing Countries & -5.7 & -5.0 & 48.5 & 48.5 \\
\hline
\end{tabular}

Source: IMF 2021.

However, there is no doubt about the contribution of the Global fiscal support in 2020, which is estimated at $\$ 14$ trillion, in saving lives and healing economies. Thus, once again confirmed that the fiscal incentives represent a powerful tool for dealing with severe and deep recessions.

Economic impacts of the COVID-19 crisis in North Macedonia 
In the Republic of North Macedonia, as one of the seriously affected countries by the COVID19 pandemic, all aspects of life, such as economic activity, education, social security, workplaces, incomes etc. have been affected severely by the crisis. Economic implications of the crisis in North Macedonia are further analyzed by the movement of the key macroeconomic aggregates.

\section{GDP}

In 2019, the total GDP of North Macedonia was calculated to be 689425 million denars, and the real GDP growth rate compared to 2018 is 3.2\% (SSO 2021a). Based on the estimation performed by different relevant national and international institutions, in the fiscal 2020, it was estimated a decline of the economic growth rate of $-3.5 \%$ by the National Bank of the Republic of North Macedonia (NBRM 2020), $-3.9 \%$ by the European Commission (EC 2020), $-4.1 \%$ by the World Bank (WB 2020) and up to $-5.4 \%$ by International Monetary Fund (IMF 2020c). According to the preliminary data for 2020 , published by the State Statistical Office, has been recorded a decrease in the economic growth rate of $4.5 \%$. In the first quarter, a slight increase of the growth rate of $0.9 \%$ was registered, but in the second quarter of 2020 was registered the highest decrease of the economic activity, $14.9 \%$. In the next quarters, third and fourth, a negative economic growth rate was registered, of $-3.3 \%$ and $-0.7 \%$ respectively (Graph 3 ).

\section{Graph 3. GDP growth rate (\%) in the Republic of North Macedonia}

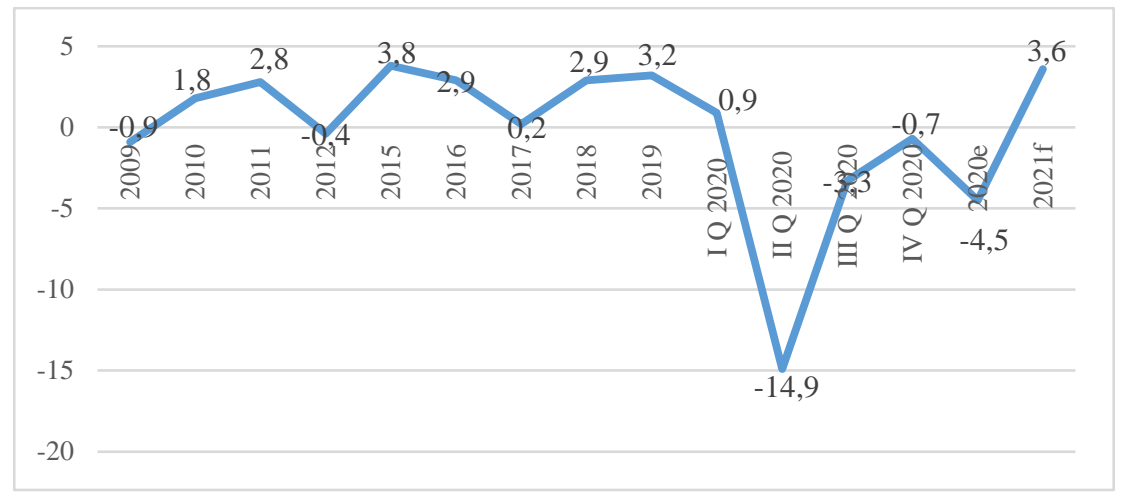

Source: SSO 2021a, WB 2021.

Notes: $\mathrm{e}=$ estimate, $\mathrm{f}=$ forecast.

The recession sharply eased in the fourth quarter. The repercussions of the financial crises 2007-2009 had resulted in a decline of economic activity of $-0.9 \%$ in 2009 and $-0.4 \%$ in 2012 . This indicates that the economic impacts of COVID-19, measured by GDP growth rate fluctuations are much higher compared with the repercussions of the Great Recession 20072009.

According to the World Bank estimates it is expected the recovery of the Macedonian economy to be much slower than the initially expected. The economic growth is expected to reach $3.6 \%$ in 2021 , if the vaccination process is accelerated, further lockdowns will not be imposed, and the external demand will increase. In the latest report the World Bank projects that the Macedonian economy will recover and return to the level before the pandemic at the beginning of 2022 (WB 2021).

\section{Industrial production}

The industrial production index in North Macedonia in 2019 was 103.7, indicating an increase of $3.7 \%$ compared with the previous year. In 2020 the industrial production was strongly hit by 
the crisis initiated as a consequence of the COVID-19 pandemic. Based on the official calculation, the industrial production index in 2020 was 90.45 i.e. in 2020 was realized a decrease in the industrial production of $9.55 \%$ (SSO 2021b). The decrease in industrial production at the same time is a result of decreased domestic and external demand. Industrial production was also hit by the Great Recession 2007-2009, when the decrease of industrial production was $8.7 \%$ i.e. the industrial production index was at a level of 91 .3. During 2020 the highest decline in industrial production was reached in April, when the decline was $33.5 \%$ compared with the April previous year. The industrial production in the manufacturing industry decreased by $40.5 \%$. The decrease in industrial production coincides with the first lockdowns in the country. In the next months, after April, the industrial production continues to decrease, by the end of the year (Graph 4). Only in the last month, December, was recorded a slight increase in the industrial production of $2.5 \%$. The highest increase was realized in the sector mining and quarrying (10.2\%).

\section{Graph 4. Industrial production volume indexes and confidence indicators in the manufacturing industry, by months, 2020.}

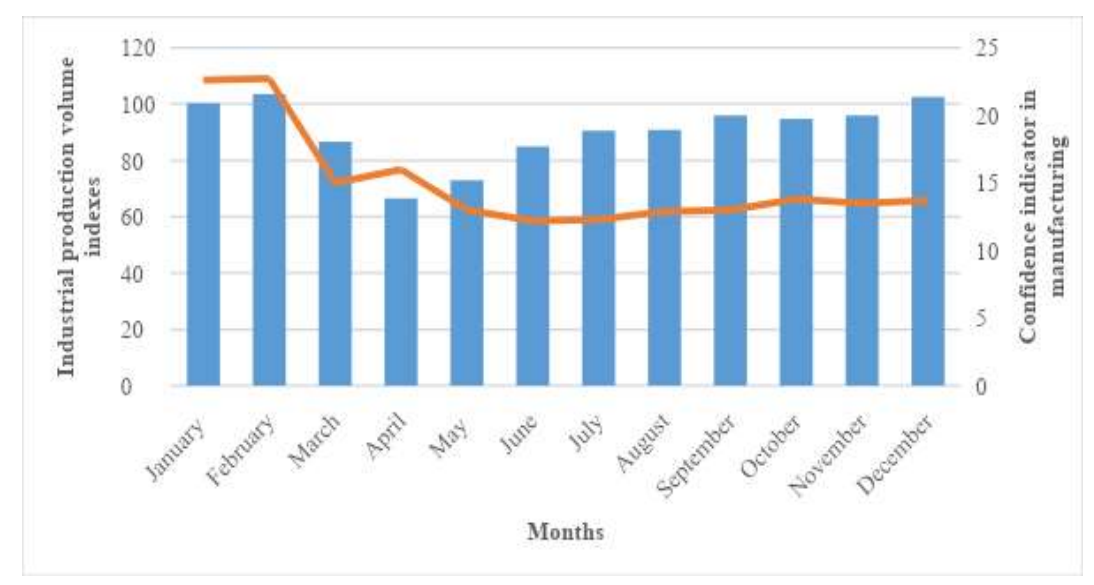

Source: SSO 2021b.

\section{Foreign trade}

The main channel through which are transmitted the negative effects of the changes in economic activity between the countries is foreign trade. This is evident for North Macedonia as a small and open economy. North Macedonia in the last years has expanded the trade with international partners and improved the integration process into the Global value chains. The trade openness index has increased from 90 points to over 135 points in 2019 and this improvement is mainly a result of the foreign direct investments located in the technologicalindustrial development zones, which are exporting mainly industrial goods part from the global value chains. The total value of exported goods from the country in 2020 amounted to 5777 905 thousand euros i.e. a decrease of $10 \%$ compared to 2019 was realized. The total value of imported goods amounted to 7594537 thousand euros, compared to the previous year the equal decrease of $10 \%$ as for export was realized (SSO 2021c). This indicates that the trade deficit does not change a lot, compared with the previous year. Import coverage by export in 2020 was $76.1 \%$ and has stayed at the same level compared to 2019 . The movement of import, export and trade deficit in 2019 and 2020 (in total and quarterly) are shown in Graph 5.

\section{Graph 5. Import, export of goods and trade deficit}




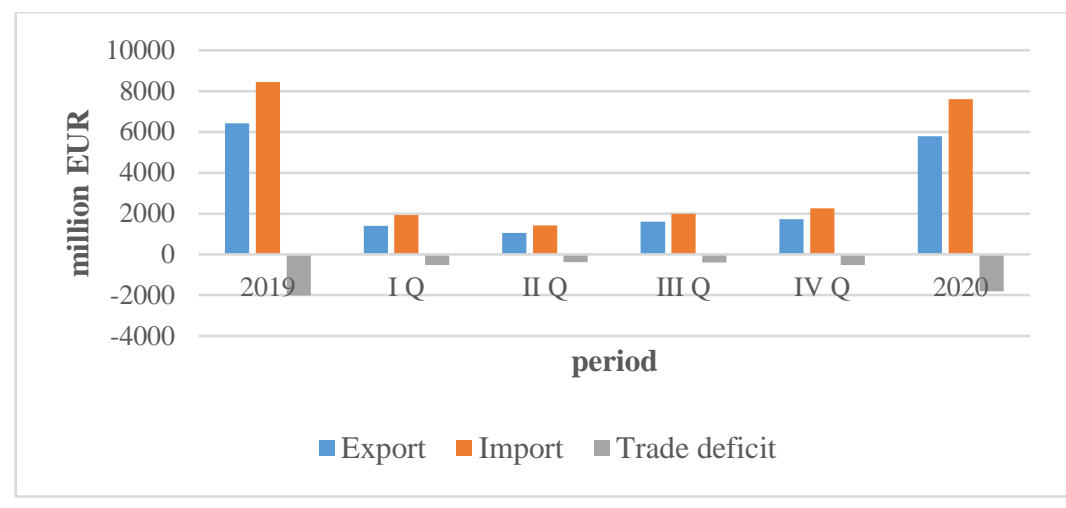

Source: NBRM 2021.

The decrease in export is having high negative impact on the economic activity in the country. The decrease in export is mainly result of several factors. Firstly, the decrease in export is a result of the severe recession caused by the COVID-19 pandemic in Europe as country's most relevant export area. According to the external trade data for 2020, the most important trade partners of the Republic of North Macedonia were Germany, Great Britain, Serbia, China and Greece. All these countries are highly hit by the pandemic which has an impact on the country's foreign trade. Secondly, the decrease of the export is a result of a decrease of export of manufacturing goods part of global value chains. The export of manufacturing goods accounts for $50 \%$ of the total export of the Macedonian economy. In the export of manufacturing goods is mainly dominating the export of semi-finished products, parts and components for the automotive industry, which was highly hit by the pandemic and faced with the shock at the demand and at the supply side. Thirdly, the inflow of foreign direct investments has also decreased from 363.3 million euros in 2019 to 205.7 million euros in 2020. Their share in GDP has also decreased, from 3.2\% in 2019 to $1.9 \%$ in 2020 (NBRM 2021). This has negative consequences to the export side of the country, because the foreign investors are the leading exporting companies in the country.

\section{Labour market}

In this period of health and socio-economic crisis, in the case of the labour market it has been crucial to choose between reduced disease exposure and financial impact on the labour market. The government financial support intended for supporting the jobs have helped to relativize the impact of the COVID-19 pandemic on the labour market in North Macedonia. The unemployment rate in 2019 was at the historical lowest level of $17.3 \%$, the employment rate was $47.3 \%$ and the activity rate in this period was $57.2 \%$. In the first quarter of 2020 in the labour market were evident some improvements, the unemployment rate has slightly decreased to $16.2 \%$, while the employment rate and activity rate have slightly increased, $48.1 \%$ and $57.4 \%$, respectively. At the peak of the crises, in the second quarter, when the numerous lockdown measures were put in place and numerous economic activities were temporary closed, the unemployment rate has increased to $16.7 \%$ i.e. 0.5 percentage points compared with the first quarter. But as a result of the government job retention subsidies and support for employment benefits was managed the fallout of the employment rate to $16.5 \%$ in the third quarter, up to $16.1 \%$ in the fourth quarter. The unemployment rate remained largely unchanged and declined to $16.4 \%$ in 2020 i.e. 0.9 percentage points below compared with 2019. The improvement in the labour market was not due to the rise in employment rate, but was due to the decrease of activity rate (Graph 6).

Graph 6 . The activity rate, employment rate and unemployment rate 


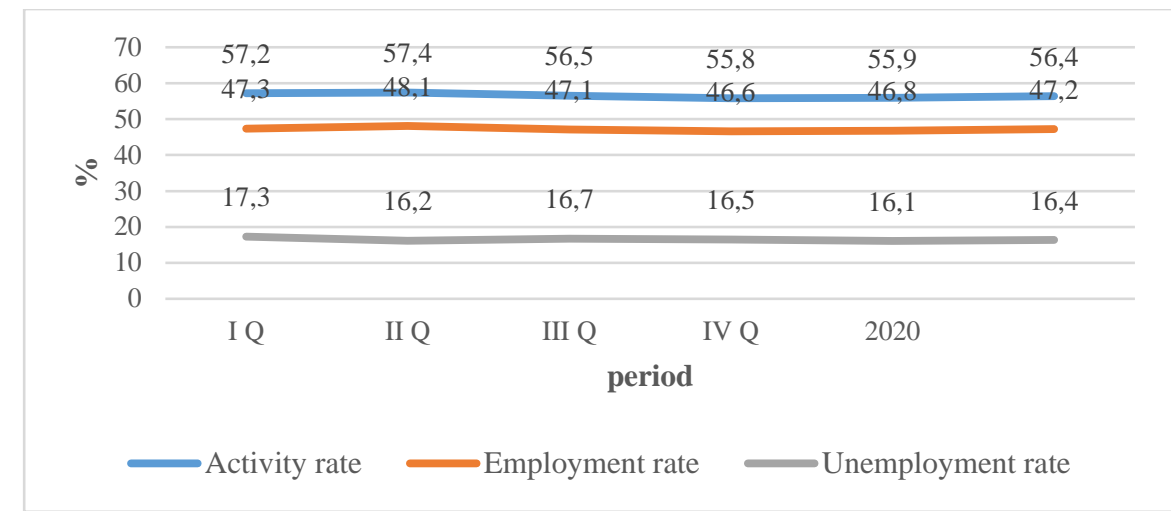

Source: SSO 2021d.

The decrease in the employment rate in the country indicates that the labour force is discouraged from looking for a job, some are part form the informal economy and some are working abroad on seasonal jobs.

During 2020, the analysis by economic sectors shows that the highest employment losses were evident for the following sectors: agriculture, forestry and fishing; electricity, gas, stream and air conditioning supply; construction; transport and storage; real estate activities; accommodation and food storage activities. On the other side in: information and communication; education; human health and social work activities, manufacturing industry; wholesale and retail sale; mining and quarrying, the employment rate has increased (SSO 2021d).

\section{Social impacts of the COVID-19 crisis in North Macedonia}

The crisis caused by COVID-19 in North Macedonia, besides the health and economic impact, has a strong social impact.

North Macedonia in the past decade has recorded a relatively favourable trend in poverty reduction, which from $27 \%$ in 2010 has decreased to $21.9 \%$ in 2018 , i.e. to $21.6 \%$ in 2019 (SSO 2020).

However, before the coronavirus-initiated crisis, about 450 thousand people in the country were living below the relative poverty line, while the percentage of people that were living below the absolute poverty line (less than US\$1.9 per day per person in purchasing power parity) was about $4.6 \%$, which is equivalent to nearly 100 thousand people (Finance Think 2020).

Hence, the crisis caused by the spread of the coronavirus is certain that will have serious implications to the poverty growth in the country.

According to the World Bank, about $16.8 \%$ of the population in North Macedonia are still leaving in poverty (using the US\$ 5.5/day at 2011 PPP) in 2019. Based on the World Bank's latest estimations, the poverty in the country has increased between 1 and 4 percentages in 2020 as a result of the recession caused by the COVID-19 pandemic (WB 2021).

The combined effects of reduced remittances, reduced incomes due to the job losses and stagnation or reduction in salaries of employees in the most affected sectors based on the use of a subsidy in the amount of 14.500 denars per employee in companies that have experienced a drop greater than $30 \%$ of revenues during the pandemic, are the key pointing factors for the high probability of poverty growth in the country in the next period.

This risk is particularly pronounced among the categories of the population with lower income, given that they are more often employed in vulnerable sectors and sectors that were severely 
affected by the crisis (such as trade and transport), they are more often recipients of social transfers and remittances and they are more common in the informal economy.

Income distribution inequality measured by the Gini coefficient shows a decrease in income inequality in North Macedonia in recent years. The Gini coefficient in North Macedonia has decreased from $32.5 \%$ in 2017 to $30.7 \%$ in 2019. According to the available data and estimates the pandemic has a significant impact on economic inequality almost in all countries. However, official inequality data are available at low frequency in the country, but according to some estimation the Gini coefficient has increased from 30\% in the first quarter of 2020 to $33.5 \%$ in the second quarter of 2020 , which presents a very high increase for a relatively short period. Most hit are people with incomes around minimum wage, women and young people and employees in labour - intensive industries (ZMAI 2021).

Additionally, the crisis due to the need of maintaining physical and social distance has caused serious problems in education related to difficulties in normal teaching and knowledge testing, especially in rural areas, disabled practical teaching and training of students, disabled or delayed specialties abroad, etc. This will deliver negative implications in the sphere of human capital formation in the future period.

Interrupted communication between people in North Macedonia has also produced negative psychological consequences, disappointment, depression, increased domestic violence, etc.

\section{Macroeconomic stimulus}

As a response to the crises caused by COVID-19 several measures as part of the monetary policy were introduced by the National Bank of the Republic of North Macedonia. To support the economy, the National Bank reduced the key monetary policy rate by 25 base points to a historic level of 1.25 percent. It also introduced a preventive measure to temporary limit the distribution of dividends to banks' shareholders in order to further strengthen the banking system in the period of crises. The inflation rate remained low and stable at $1.2 \%$ in 2020 .

North Macedonia as almost all countries besides undertaken measures for the containment and mitigation of the spread of COVID-19, has established fiscal measures through stimulus packages in order to reduce the socio-economic impact caused by the crises. The fiscal measures are mainly oriented through: 1) preserving the living standard of the population, by supporting incomes and 2) supporting the companies. The stimulus intended for companies are multidimensional and segmented by the activity and the size of the companies. During 2020 were implemented 4 packages of measures. The total value of implemented measures is around 1 billion and 20 million EUR. The fiscal stimulus of implemented measures is 704 million EUR, i.e. $6.5 \%$ of GDP2. The response of the fiscal policy was relatively fast and has significantly positive effect on supporting companies and employees in the most affected industries and the most vulnerable groups in mitigating the negative impact of COVID-19 on households' incomes and business activities. Hence it is estimated that without the fiscal stimulus the decrease in economic activity would be $8.4 \%$, compared with the measured decrease of GDP of $4.5 \%$. In February 2021 was implemented the $5^{\text {th }}$ package of measures and in April was implemented the $6^{\text {th }}$ package. With the measures were covered households and companies, but the effects form those measures are not calculated jet.

The general budget deficit as percentage of GDP has increased by 4 times in 2020 (8.5\%) compared with $2019(2 \%)$, as a consequence of the crises (Graph 7). The high increase of the general budget deficit is a result of decrease of budget revenues, accompanied with increase

\footnotetext{
${ }^{2}$ https://koronavirus.gov.mk/merki/
} 
of budget expenditures. Mainly budget revenues have decreased as a result of the lower private consumption, the decrease of VAT, excise revenues and decrease of non-tax revenues. On the other side the budget expenditures have increased mainly as a result of the increase of health and social protection expenditures, assigned subsidies intended for job retaining, increase of pensions and minimal wage (MF 2021).

\section{Graph 7. The general government deficit as \% of GDP}

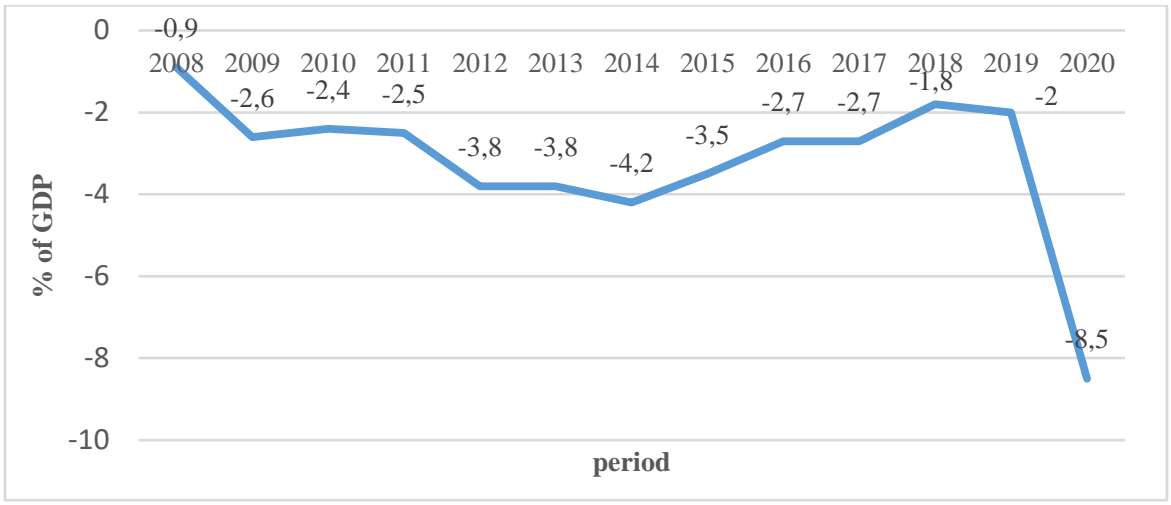

Source: MF 2021.

At the same time the public debt during 2020 has increased as a result of the regular refinance payments due, financing of increased budget deficit and implemented stimulus packages for reduction of socio-economic impact on the economy. The public debt has reached $60 \%$ of GDP in 2020, which presents 10 percentage points increase compared with 2019 (Graph 8).

\section{Graph 8. Public debt as \% of GDP}

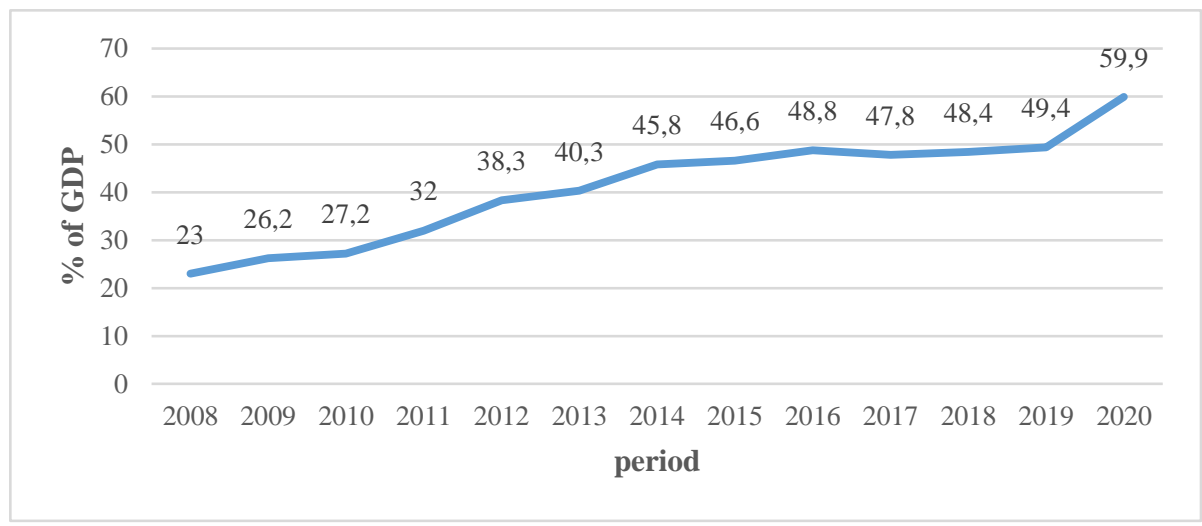

Source: MF 2021.

\section{Conclusion}

The crises caused by the COVID-19 pandemic which started as a health crisis has not only impacted human health but has also wide-scale impacts on economic and social parameters and is one of the greatest challenges that the World faces after the World War Second. 
COVID-19 pandemic has caused a serious decline in economic activity, serious distortions in the labor markets and strong social implications worldwide.

The COVID-19 outbreak and lockdowns have also negatively impacted the economic activity in North Macedonia. The GDP growth rate has decreased by $4.5 \%$ in 2020 , a decrease of almost $10 \%$ in the industrial production was reached and the negative impacts are evident in almost all economic sectors.

Besides the unemployment rate does not dramatically changed in 2020 compared with 2019, the employment rate and activity rate have decreased compared with 2019 , meaning that the crisis also impacted the labour market. The crisis has increased the poverty rate in the country and at the same time according to some national estimations the income inequalities have realtively highly increased, but official data are not available yet. Interrupted communication between people has also produced negative psychological consequences, disappointment, depression, increased domestic violence, etc.

The government's financial stimulus helped to mitigate the negative impact on the labour market and to mitigate the socio-economic impact of the crises in North Macedonia. But fiscal space as a result of implemented measures is relatively limited, as the general budget deficit reached $-8.5 \%$ and public debt reached almost $60 \%$ of GDP.

Having in mind the limited fiscal space of North Macedonia, in the later stages of the crisis and in the period of economic recovery, in addition to the established state measures to support the economy and the vulnerable categories of population, it is necessary the policy makers to take in consideration the following aspects:

- In order to be reached the forecast growth rates and to recover the national economy in the following years, the vaccination process should be accelerated with aim further lockdowns not to be put in place, and the investor and consumer confidence should be improved in order to be increased the investment process and private consumption;

- Reduction of the budget deficit should be one of the top priorities for the next period. The level of realization of the budget should be improved in, by enhancing the management of public institutions. On the expenditures side should be increased the capital investments mainly intended for green growth, education and health and unproductive expenditures should be cut off. On the revenues side should be strengthen public revenues by widening the tax base in a non-regressive way, and fighting against tax evasion and informal economy should be intensified.

- The public debt is becoming a central problem in the country, as in almost all other economies. In the next years the further accumulation of the public debt should be avoided. The level of public debt should be planned in accordance with the budget deficit and growth rates. The fiscal roles should be respected. The rigorous cut offs should not be considered in order not to have further negative implications on growth rates;

- The government support measures for companies and households should continue in 2021, but the measures should be intended for recovery of the economy, in function for support of entrepreneurship, SMEs, innovation and advanced technologies, which will support building up digitalized, green and innovation economy in the path of achieving sustainable development;

- Human capital should be improved as one of the main factors for achieving sustainable growth in future. The weak human capital in the country is result of the weak education system and limited workforce skills acquisition, which together lead to low productivity. In order to straighten the human capital urgent reforms in the education system and in the labour market should be implemented; 
- The process of implementing economic, social and political reforms should continue and should be accelerated in future with main aim of building new dynamic economic growth model for overcoming the current consequences caused by COVID-19 crisis.

\section{References}

1. Eurostat (2021a). Long-term unemployment - quarterly data. Available at: https://appsso.eurostat.ec.europa.eu/nui/show.do?dataset=une_ltu_q\&lang=en.

2. Eurostat (2021b). Unemployment by sex and age - annual data. Available at: https://appsso.eurostat.ec.europa.eu/nui/show.do?dataset=une rt a\&lang=en.

3. European Commission (2020). European Economic Forecast, Spring 2020, institutional paper 125. Available at: https://ec.europa.eu/info/sites/default/files/economy-finance/ip125 en.pdf.

4. Finance Think (2020). To what extent will COVID-19 increase poverty in North Macedonia? Policy Brief No. 43. Available at: https://www.financethink.mk/wpcontent/uploads/2020/11/PB43.pdf.

5. Institute of Public Health (2021). Press release 20.04.2021. Available at: http://iph.mk/wpcontent/uploads/2021/04/20.4.pdf.

6. International Labour Organization (2020). ILO Monitor: COVID - 19 and the world work, Fourth edition.

7. International Labour Organization (2021). ILO Monitor: COVID-19 and the world of work. Seventh edition.

8. International Monetary Fund (2020a). World Economic Outlook, April 2020.

9. International Monetary Fund (2020b). World Economic Outlook, Update, June 2020.

10. International Monetary Fund (2020c). World Economic Outlook - A Long and Difficult Ascent, October 2020.

11. International Monetary Fund (2021). World Economic Outlook, April 2021.

12. Li H, Liu SM, Yu XH, Tang SL, Tang CK. (2020). Coronavirus disease 2019 (COVID-19): current status and future perspective. Int J Antimicrob Agents 105951:105951.

13. Ministry of Finance of Republic of North Macedonia, Citizens Budget, Deficit. Available at: http://budget.finance.gov.mk/\#.

14. National Bank of the Republic of North Macedonia (2021). Statistics. Basic Economic Data and Residential Real Estate Prices, Table Basic Economic Data. Available at: https://www.nbrm.mk/osnovni ekonomski pokazateli-en.nspx.

15. National Bank of the Republic of North Macedonia (2020). Quarterly Report, Macroeconomic forecasts and risks, May, 2020. Available at: https://www.nbrm.mk/content/Macroeconomic\%20Forecasts\%20Quarterly\%20Report\%20Ma y\%202020.pdf.

16. OECD (2021). The COVID-19 crisis in North Macedonia, 31 January 2021. Available at: https://www.oecd.org/south-east-europe/COVID-19-Crisis-in-North-Macedonia.pdf.

17. State Statistical Office (2020). Laeken poverty indicators in 2019, News Release No. 4.1.20.113, from 14.12.2020, Skopje. Available at: http://www.stat.gov.mk/PrikaziSoopstenie.aspx?rbrtxt=115.

18. State Statistical Office (2021a). Gross Domestic Product, fourth quarter 2020, News Release No. 3.1.21.04, from 02.03.2021, Available at: https://www.stat.gov.mk/PrikaziSoopstenie.aspx?rbrtxt=31.

19. State Statistical Office (2021b). MakStat Database. Industry. Industry 2015=100. Table Indices of industrial production, previous year $=100$. Available at: http://makstat.stat.gov.mk/PXWeb/pxweb/en/MakStat/?rxid=46ee0f64-2992-4b45-a2d9cb4e5f7ec5ef. 
20. State Statistical Office (2021c). External trade, January - December 2020, News Release No. 7.1.21.02, from 08.02.2021

Available

at: https://www.stat.gov.mk/PrikaziSoopstenie.aspx?id=78\&rbr=13540.

21. State Statistical Office (2021d). Active Population in the Republic of North Macedonia, Results from the Labour Force Survey, 2020, News Release No. 2.1.21.05, from 19.03.2021. Available at: https://www.stat.gov.mk/PrikaziSoopstenie.aspx?id=98\&rbr=13584.

22. Waris A, Khan AU, Ali M, Ali A, Baset A (2020). COVID-19 outbreak: current scenario of Pakistan. New Microbe New Infect 35:100681.

23. World Health Organization (2021). WHO Coronavirus Disease (COVID-19) Dashboard. https://covid19.who.int/.

24. World Bank (2020). Western Balkans Regular Economic Report No. 17 / spring 2020, The Economic and Social Impact of COVID-19. Available at: http://documents1.worldbank.org/curated/en/606131588087679463/pdf/The-Economic-andSocial-Impact-of-COVID-19-Western-Balkans-Outlook.pdf.

25. World Bank (2021). Western Balkan Regular Economic Report No.19/spring 2021, Subdued Recovery. Available at: http://documents1.worldbank.org/curated/en/489271619450269031/pdf/Subdued-RecoveryThe-Country-Notes.pdf.

26. Zdruzenie za istrazuvanje i analizi (2021). Neednakvost vo vreme na korona (Efekti od pandemijata na covid-19) (Association for Research and Analysis (2021). Inequality during the Corona (Effects of the COVID-19 pandemic on the Macedonian economy). Available at: https://zmai.mk/wp-content/uploads/2021/01/Efektite-od-Kovid-vrz-MK-ekonomija-MK.pdf). 